接着継手の混合モード破壊基準

$$
\begin{array}{lllll}
\text { 結 城 良 } & \text { 治* 鄭 } & \text { 南 } & \text { 龍** } \\
\text { 石 川 晴 } & \text { 雄*** } & \text { 中 野 } & \text { 禪**** }
\end{array}
$$

\title{
Mixed Mode Fracture Criteria on Adhesive Joints
}

\author{
by \\ Ryoji YUUKI*, Nam-Yong ChUnG**, Haruo IsHIKAWA*** \\ and Shizuka NAKANO****
}

This study investigates the problem of applying fracture mechanics to evaluation of the strength of adhesive joints, focusing on mixed mode fracture criteria. Various types of adhesive joint specimens with a crack in an adhesive layer were prepared for the static tests and fatigue tests. The adherend was acryl plate and epoxy plate and the adhesive was cemedine 1500 and EP-007. The energy release rates $G_{1}$ and $G_{I I}$ for various adhesive joints were analyzed by FEM and modified virtual crack extension method. Comprehensive mixed mode conditions from pure mode I to nearly pure mode II were realized in this study. The fracture toughness results obtained showed a mixed mode fracture criterion peculiar to adhesive joints, which can be characterized by $G_{\mathrm{I}}$ and $G_{\mathrm{II}}$. It was found that the fatigue crack growth rate in various adhesive joints can be well characterized by the total energy release rate range $\Delta G_{\mathrm{T}}$. Therefore, different approaches are necessary for the fatigue crack growth and fracture toughness of adhesive joints under mixed mode conditions.

Key words : Adhesive joint, Fatigue crack growth, Cyclic debonding, Fracture toughness, Mixed mode crack, Energy release rate, Fracture mechanics

\section{1 緒 言}

構造用接着剂の発展に伴い, 構造の合理化および軽 量化を目的として接着継手が各種分野に適用されつつ あるが, 接着継手・構造の設計および強度評価にはま だ多くの課題が残されている. 従来, 接着継手の強度 評価法として公称応力基準が用いられてきたが，この 強度評価法は継手形状・負荷形式の異なる場合に適用 できず，また接着界面端の局所応力やひずみを用いる 評価法も提案されているが, その点の応力特異性の問 題もあり, 定量的評価法に至っていないのが現状であ る.

最近, 接着継手の強度評価法として, 破壊力学を用 いた評価法が注目されている。玄なおち, 接着継手の 強度は接着界面ないし接着層内のき裂の発生・成長過 程により決まり，これを破壊力学的に評価・解析し， 定量的評価法を確立しようとするものである. しかし， 接着継手中のき裂は一般に混合モードとなり, その破 壊力学パラメー夕の評価・解析に困難を伴い, また混 合モード破壊基準も明確ではないのが現状である.
あて, 混合モード状態が広範囲に異なる各種の接着継 手の静的破壊試験および疲労き裂伝ば試験を行ない, 接着継手特有の混合モード破壊基準について検討した.

\section{$2 \cdot 1$ 被着材と接着刘}

\section{2 実 験 方 法}

本研究ではき裂が直接観察できる透明材料のアクリ ル樹脂とエポキシ樹脂を被着材として採用した。 また 接着剂として 2 液混合夕イプのエポキシ系接着剤セメ ダイン 1500 と EP-007を使用した. 被着材および接 着剂の機械的性質を Table I に示す. 主材と硬化剂 （いずれもポリアミド）の混合比は $1: 1$ とした.

Table I. Mechanical properties of adhesives and adherends.

\begin{tabular}{c|c|c|c|c}
\hline \multicolumn{2}{c|}{ Mechanical properties } & $\begin{array}{c}\text { Young's } \\
\text { modulus } \\
E \mathrm{MPa}\end{array}$ & $\begin{array}{c}\text { Poisson's } \\
\text { ratio } \\
\nu\end{array}$ & $\begin{array}{c}\text { Tensile } \\
\text { strength } \\
\sigma_{b} \mathrm{MPa}\end{array}$ \\
\hline \multirow{2}{*}{ Specimen materials } & Acryl & 2941.2 & 0.345 & 61.8 \\
\hline \multirow{2}{*}{ Adherends } & Epoxy & 2431.4 & 0.34 & 61.5 \\
\cline { 2 - 5 } & Cemedine 1500 & 2058.8 & 0.4 & \\
\cline { 2 - 5 } & " EP-007 & 1127.5 & 0.41 & \\
\hline
\end{tabular}

\begin{tabular}{|c|c|}
\hline$\dagger$ & 平成元年11月 4 日 $\quad$ Received Nov. 4, 1989 \\
\hline$*$ & $\begin{array}{l}\text { 正会 員 東京大学生産技術研究所 東京都港区六本木, Institute of Industrial Science, University of Tokyo, Roppongi, Minato-ku, } \\
\text { Tokyo }\end{array}$ \\
\hline $\begin{array}{l}* * \\
* * * \\
* * * *\end{array}$ & $\begin{array}{l}\text { 崇田大学校 韓国ソウル市, Soong Jun University, Seoul, Korea } \\
\text { 正 会 員 電気通信大学 調布市調布ケ丘, University of Electro_Communications, Chofugaoka, Chofu } \\
\text { 機械技術研究所 つくば市並木, Mechanical Engineering Laboratory, Namiki, Tsukuba }\end{array}$ \\
\hline
\end{tabular}
本研究では接着継手の混合モード破壊基準に焦点を 


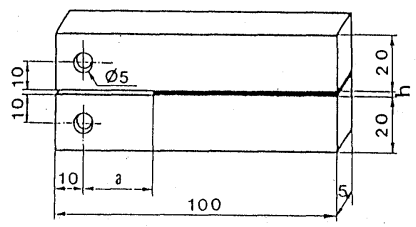

(a) Double-cantilever beam (DCB) specimen

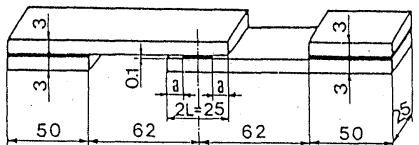

(b) Single-lap joint (SLJ) specimen

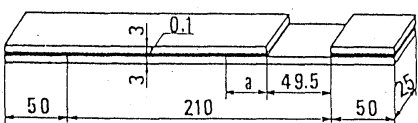

(c) Cracked-lap shear (CLS) specimen

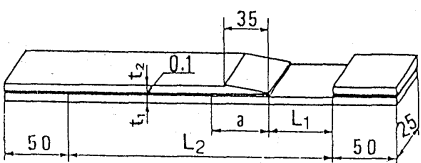

\begin{tabular}{|c|c|c|c|c|}
\hline $\begin{array}{c}\text { Dimensions } \\
\text { Specimens } \\
\end{array}$ & $\mathrm{L}_{1}$ & $\mathrm{~L}_{2}$ & $t_{1}$ & $t_{2}$ \\
\hline$T C L S-A$ & 49.5 & 210 & 3 & 3 \\
\hline TCLS-B & 100.5 & 261 & 3 & 3 \\
\hline$T C L S-C$ & 49.5 & 210 & 1.5 & 3 \\
\hline
\end{tabular}

(d) Tapered-cracked-lap shear (TCLS) specimen

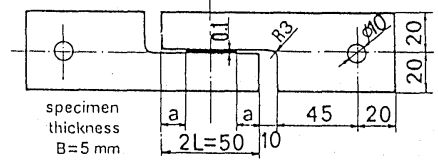

(e) Cracked-shear (C S) specimen

Fig. 1. Shapes and dimensions of various adhesive joints.

$$
G_{T}=G_{\mathrm{I}}+G_{\mathrm{II}}=\frac{P^{2}}{2 B} \cdot \frac{d C}{d a}
$$

ここで $P$ は負荷荷重, $B$ は板厚, $a$ はき裂長, $C$ はコンプライアン スである．全エネルギ解放率 $G_{T}$ はコンプライアンスの変化率を実 測することにより求められる。し かし，モードIおよびモードIIに 対応する $G_{1}$ と $G_{11}$ の分離評価に は特別の工夫が必要となる. 本研 究ではこの分離評価に FEM 解析 を援用することにした。

まず接着層中に各種の長さのき 裂を想定し, FEM 弾性解析を行 ない, 著者らが開発した改良仮 想き裂進展法の基づくパソコン用 ポストプロセッサー CRACK

\section{$2 \cdot 2$ 試験片の作成}

本研究では Fig. 1 に示す 5 種類の接着継手試験片を 用意した．いずれも被着材は同一として，純粋モード I となる DCB 継手から，混合モードとなる SLJ 継 手，CLS 継手さらにモードIが支配的となる TCLS 継手，CS 継手を試験に供した。

各試験片の接着は被着材と所定の寸法に機械加工後, 接着面を\#1000 のエメリーペーパで十分研磨し，ア セトンで洗浄後, 水洗いして乾燥し, 上述の接着剤を 用いて加圧力および接着厚さが一定となるように接着 治具に固定したまま電気炉内で $60^{\circ} \mathrm{C}, 2$ 時間硬化処 理を行なった。

各試験片の予き裂導入に際しては接着層の厚さを一 定に保つため，試験片の両側にテフロンシートをはさ み接着した．各試験片の接着層の厚さはアクリルの場 合 $0.1 \mathrm{~mm}$ ，エポキシの場合約 $0.02 \mathrm{~mm}$ とした.

\section{$2 \cdot 3$ 試験方法}

静的試験はき裂を入れた各種継手を変位速度 0.2 $\mathrm{mm} / \mathrm{min}$ で引張り, 荷重-荷重点変位を記録した。き 裂の成長を確認した後，除荷を行ない，き裂長さを測 定し, 再び負荷を行ない一つの試験片でき裂長さの異 なる多数の破壊じん性值を得た。また疲労試験は変位 制御下で応力比 $R=0.1$, 周波数 $3 \mathrm{~Hz}$ で行なった. き裂長さの測定は目視で行なったままた，各試験片に つき，き裂長さを変化させ，荷重-荷重点変位の測定 によりコンプライアンスを計測した。

\section{3 破壊力学パラメータの評価法}

接着継手のき裂の破壊力学パラメータとしてエネル ギ解放率 $G$ がよく用いられる。 $G$ は次式のようにコ ンプライアンスの実測から実験的に求められる利点が ある。
$/ \mathrm{PC}$ を用いて効率的かつ精度良く $G_{\mathrm{I}}$ および $G_{\mathrm{II}}$ を計 算した. $\stackrel{99}{9}$.10). 2 . 2 は Fig. 1 に示した各種継手試験片（被 着材はアクリル，接着剤はセメンダイン 1500）につ いて解析により求めた $G_{1} / G_{\text {II }}$ の比を示す. 純粋モー ド I となる DCB 継手に加え, 試験片形状を工夫する ことにより広範囲な混合モード状態が実現できること が分かる．特に CLS にテーパーをつけた TCLS-B, C タイプの試験片では純粋モードIIに近い状態であ ることが分かる.

本研究では $G_{T}$ はコンプライアンスの測定から実験 的に求め, 混合モードクライテリオンを考える場合に は $G_{1}$ と $G_{\mathrm{II}}$ の分離評価が必要となり，この分離には 解析から求めた $G_{\mathrm{I}} / G_{\mathrm{II}}$ の比を利用することにした。

4 破壊じん性と混合モードクライテリオン

\section{$4 \cdot 1$ DCB 試験片の場合}

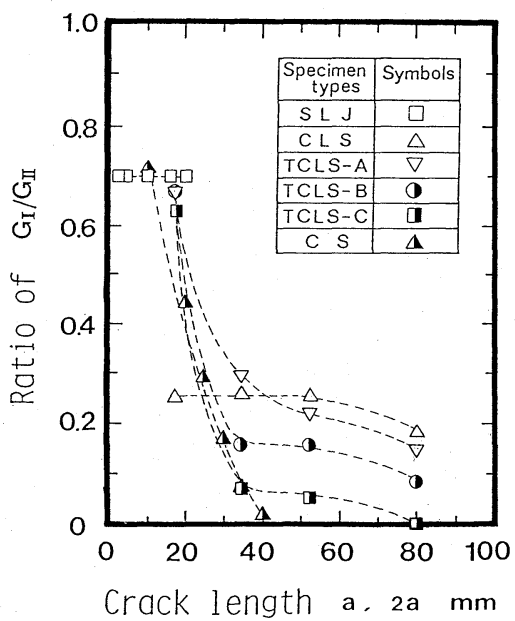

Fig. 2. Numerical results of $G_{\mathrm{I}} / G_{\mathrm{II}}$ for various adhesive joints. 
まず純粋モード I となる DCB 試験片の静的な破壊 じん性の実験結果を Fig. 3，4 亿示す. Fig. 3 は被着 材がアクリルの場合，Fig. 4 はエポキシの場合である が，いずれの場合も広範囲のき裂長さに対して，ばら つきは大きいもののほぼ一定の特性を示していると考 えられる. 接着剤はいずれの場合も同上のセメダイン 1500 を用いたが，破壊じん性の平均值はアクリルの 場合 $13.7 \mathrm{~N} / \mathrm{m}$, エポキシの場合 $134.0 \mathrm{~N} / \mathrm{m}$ となり, 1 オーダーほどの相違があることが注目される.

\section{$4 \cdot 2$ SLJ 試験片の場合}

つぎに混合モードとなる SLJ 試験片の破壊じん性 の実験結果を Fig. 5 に示す。この場合前述のように解 析から得られた $G_{\mathrm{I}} / G_{\mathrm{II}}$ の比を用いて， $G_{\mathrm{I}}$ と $G_{\mathrm{II}}$ を分 離して示した。この場合もクリティカルな $G_{c}$ 掠よび $G_{\mathrm{II}} ， G_{\mathrm{II}}$ はき裂長さの変化によらずほぼ一定となり, 破壊力学パラメータとして·Gの有効性が確認できた.

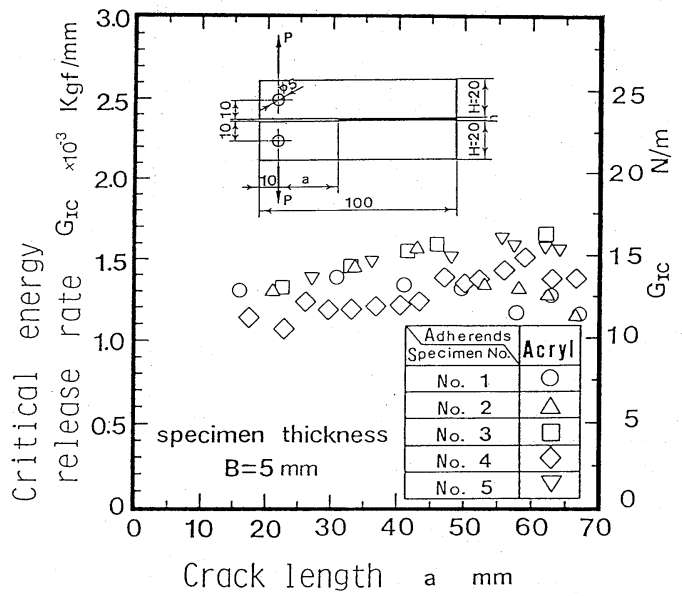

Fig. 3. Fracture toughness values of acryl DCB adhesive joints.

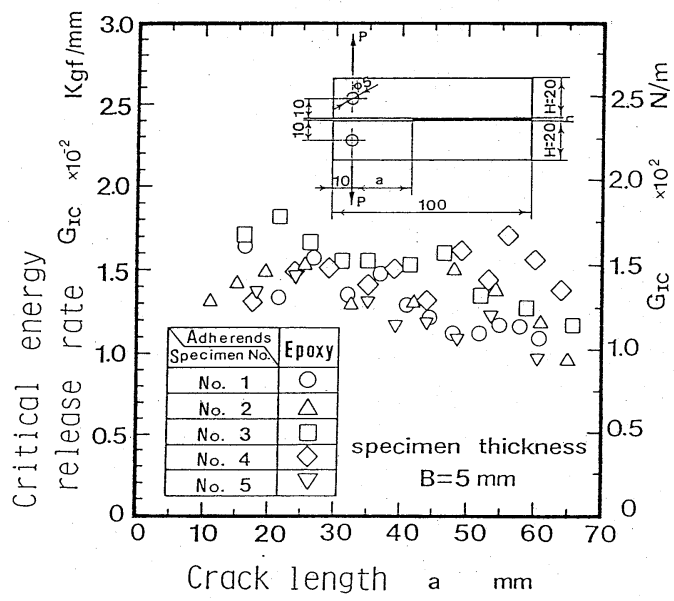

Fig. 4. Fracture toughness values of epoxy DCB adhesive joints.

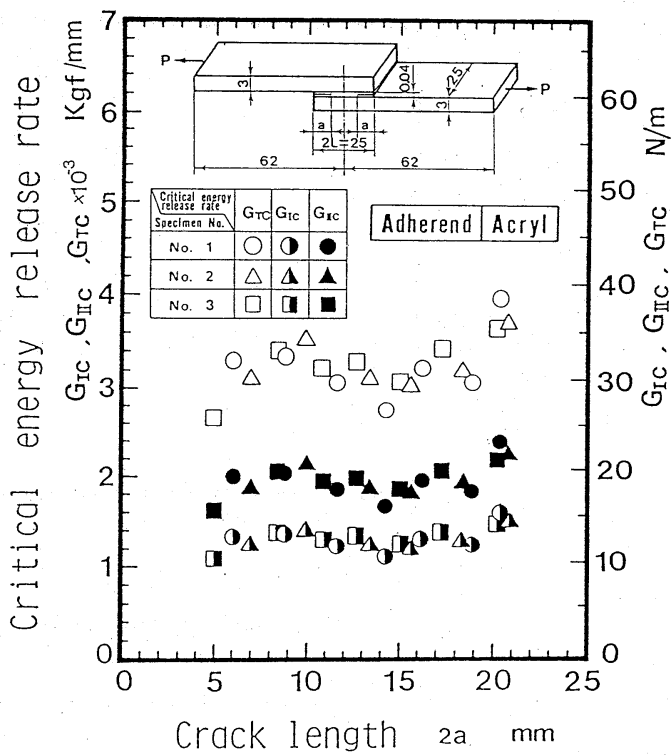

Fig. 5. Fracture toughness values of acryl SLJ adhesive joints.

Fig. 5 はアクリルを被着材としてセメダイン 1500 で 接着したものであるが，同一材抢よび同一接着剤の Fig. 3 の DCB の結果と比較して, 雨者の $G_{I c}$ はほほ 同一レベルにあり，この両者の結果のみを見る限り， 破壊じん性に及ぼすモード II 成分の寄与は極めて小さ く，モードI成分にのみ支配されているように見える. 実際，筆者らの前報や複合材料のディラミネーション に関するRybichíらもこのような結論を導いている. なお，エポキシについても SLJを用いた試験を行 なったが，すべて母材側で破壊し，デー夕が得られて いない.

\section{4・3 各種継手の混合モード破壊基準}

Fig. 6 は Fig. 1 に示したすべての継手について破壊 じん性の各モード成分值 $G_{\mathrm{II}}, G_{\mathrm{II}}$ で整理した結果を 示す．SLJよりさらにモードII成分が大きい CLS, TCLS，CS 継手では $G_{\text {Ic }}$ が低下し，接着継手固有の $G_{\text {IIC }}$ に収束する傾向がある.この $G_{\text {IIC }}$ 值は $G_{I C}$ の 3 4 倍となり,この結果は一般に接着ははく離に弱く, せん断に強いことと対応する。

従来せん断荷重を代表する試験として SLJ タイプ が主に用いられていたが，SLJだけでは不十分であ り，広範囲な混合モード状態を実現して初めて，接着 継手の混合モード破壊基準が明らかになった。

Fig. 6 はアクリルのセメダイン 1500 接着の結果で あるが，被着材を同一として，接着郕をやや弱い EP -007に変え行なった結果を Fig. 7 に示す．破壊じん 性值は低下しているが混合モード破壞基準としては同 一の傾向が得られた。

なお，本研究では破壊はモード成分によらず，すべ 


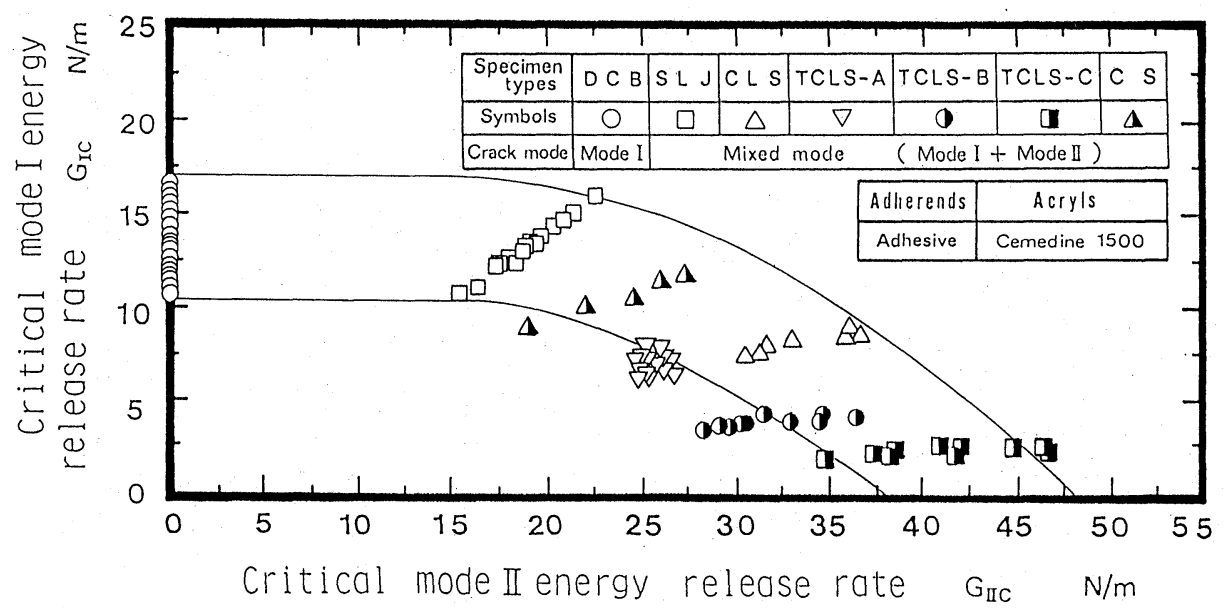

Fig. 6. Mixed mode fracture toughness for various adhesive joint (Cemedine 1500).

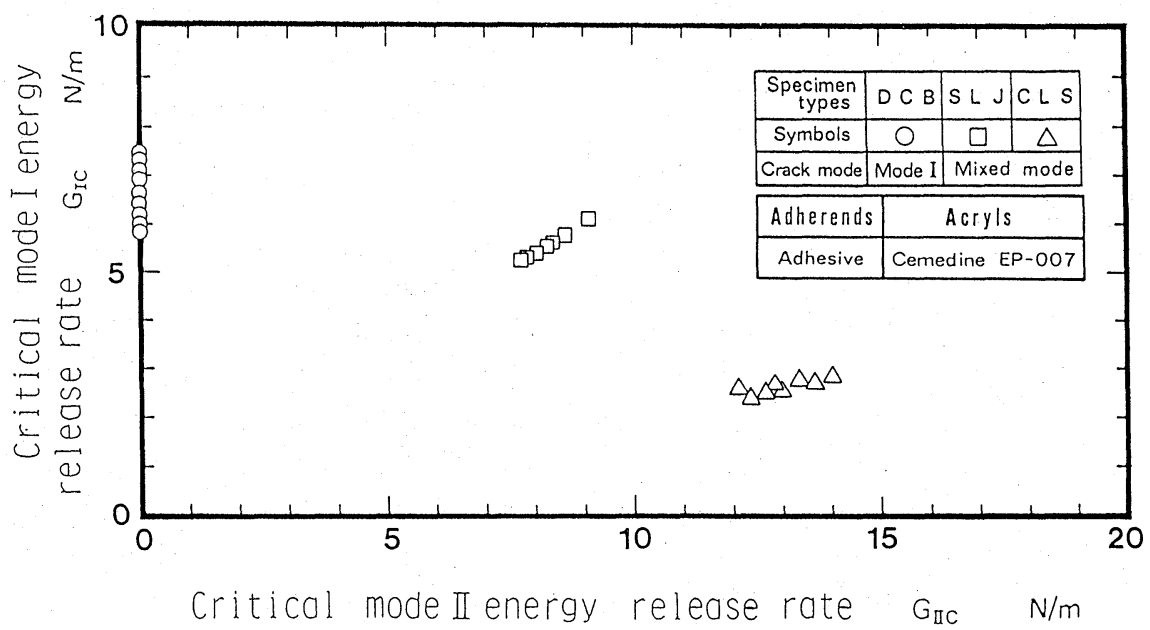

Fig. 7. Mixed mode fracture toughness for various adhesive joint (Cemedine EP-007).

て接着界面に沿って進行した.

\section{5 静的破壊の混合モード破壊基準の検討}

\section{$5 \cdot 1$ 混合モ一ド破壊基準の定式化}

以上の接着継手の破壊じん性の結果から, 混合モ一 ド破壊基準として定式化すると以下の 2 通りの方法が 考えられる. 純粋モードI の破壊じん性值を $G_{\mathrm{Ic}}^{*}$, 純

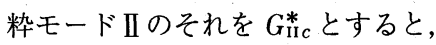

$$
\left(\frac{G_{\mathrm{I}}}{G_{\mathrm{IC}}^{*}}\right)^{2}+\left(\frac{G_{\mathrm{II}}}{G_{\mathrm{II}}^{*}}\right)^{2} \geq 1
$$

で表わすことも可能である. しかし，Fig. 6 の結果か ら $G_{1}$ が支配的な領域も存在し, 次のような 2 パラメ 一夕，2クライテリオンも考えられる.

すなわち， $G_{\mathrm{I}}$ が支配的な領域では，

$$
G_{\mathrm{I}} \geq G_{\mathrm{Ic}}^{*}
$$

また $G_{I I}$ が支配的な領域では,

$$
G_{T}=G_{\mathrm{I}}+G_{\mathrm{II}} \geq G_{\mathrm{IIC}}^{*}
$$

で再整理すると Fig. 8 となり， $G_{\mathrm{II}} / G_{\mathrm{I}}$ が大きくなる と一定ないし飽和する傾向がうかがえる．2つの考え 方を図示すると Fig. 9 となり, どちらが良いかは今後 の詳細かつ系統的な検討を必要とする.

\section{$5 \cdot 2$ 均質材の混合モード破壊基準との比較}

均質材中の混合モードき裂のクライテリオンについ てすでに多くの説があるが, 一般に $\sigma_{\theta \max }$ クライテリ オンが良く用いられる. 均質材中の混合モードき裂は 屈折し，その破壊じん性はモードIの破壊じん性に支 配されていると考えられている. 一方接着継手では混 合モードでも接着層ないし界面を直線的に進展するた め, 均質材とは全く異なるクライテリオンが必要とな る.

試みに Fig. 9 に均質材のクライテリオンも併記した. 一般に接着界面の破壊じん性・抵抗は均質母材のそれ より小さく，それ故接着界面に沿ってき裂が進展しゃ すい. 接着が強く, 被着材単体の強度が小さい場合に 


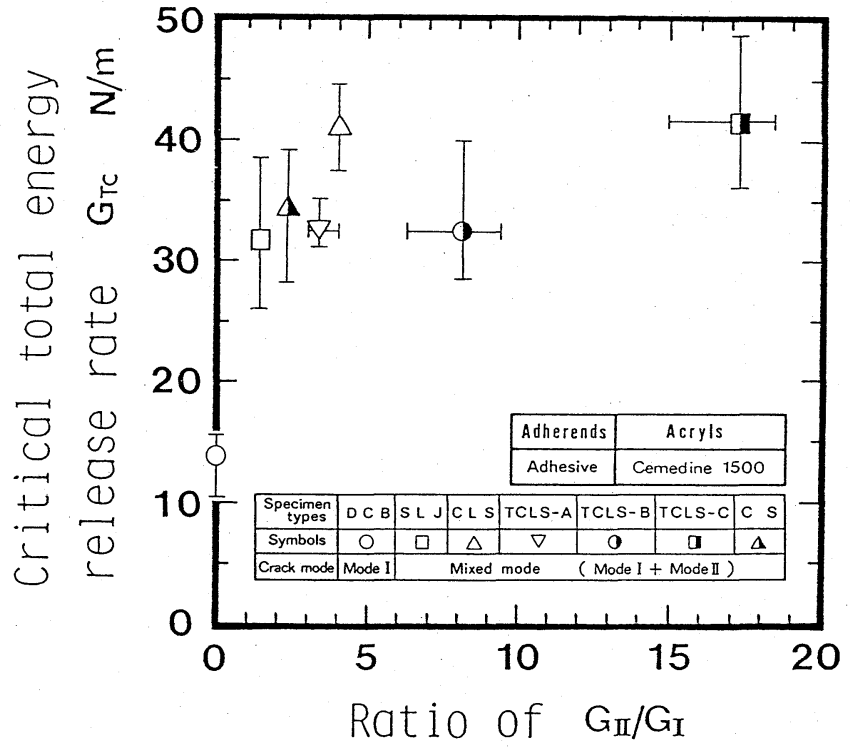

Fig. 8. Relation between critical total energy release rate and $G_{\mathrm{II}} / G_{\mathrm{I}}$.

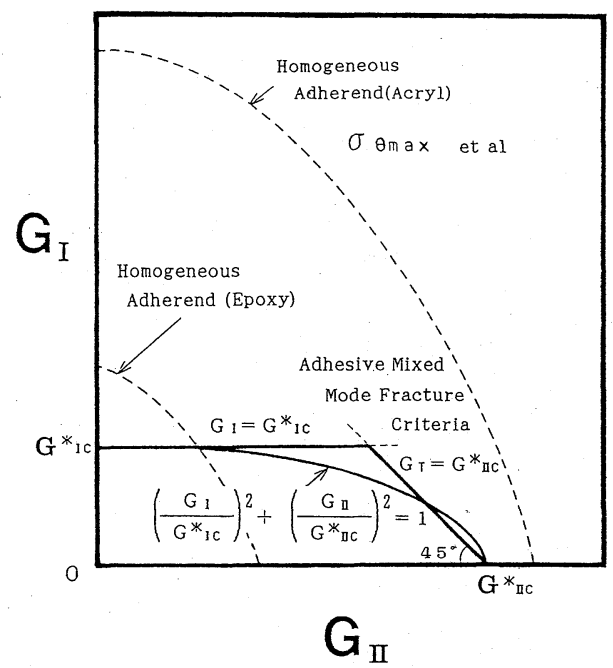

Fig. 9. Mixed mode fracture criteria for adhesive joints.

は，モードIでは接着層をき裂が進展するが，混合モ 一ドになると被着材側へき裂が進展することも生じ得 る. 実際, 本研究でもエポキシ材をエポキシ系接着剤 で接着すると，DCB ではアクリルに比べて大きな $G_{I c}$ 值が得られたが, SLJ や他の継手では母材で破壊 した．同様な現象は FRP の接着継手の実験でもしば しば見られる。.このような場合, Fig. 9 のように接着 継手および均質材の破壊じん性の混合モードクライテ リオンを同一図上にプロットすれば，母材破壊か接着 界面破壊かを容易に判定できるものと思われる.

\section{6 混合モード疲労き裂伝ぱ特性}

Fig. 1 に示す各種継手の疲労き裂伝ぱ試験も併せて
実施した.アクリルを被着材とし, セメ ダイン 1500 および EP-007 の接着継手 の疲労き裂伝ぱ速度を全エネルギ解放率 範囲 $\Delta G_{T}$ で整理した結果を Fig. 10,11 に示す．混合モード比が異なる継手のデ 一夕が $\Delta G_{T}$ で統一的に評価できること が分かる．すなわち，接着界面に沿う疲 労き裂伝ぱ速度 $d a / d N$ は, 次式で表す ことができることが明らかになっだ,12),13

$$
d a / d N=C\left(\Delta G_{T}\right)^{m}
$$

上式の材料定数 $C, m$ は継手形状 - 寸 法に依存しない接着界面固有のき裂伝ぱ 抵抗を示すものと考えられる。また， $d a / d N$ を $\Delta G_{\mathrm{I}}$ や $\Delta G_{\mathrm{II}}$ でも整理してみ たが，継手形状により全く異なった特性 となった. Fig. 11 から分かるように EP -007の方が伝ぱ抵抗が弱い。一般に接 着界面の疲労き裂伝ぱ速度は母材より早 く，かつ $m$ が大きい傾向にある. Fig. 12 は DCB 接着継手のエポキシ材の疲労き裂伝ぱ特 性の一例を示す。この場合，界面破壊，擬集破壊，被 着材破壊と破壊形態が変化する現象が生じたが，それ ぞれの破壊については $\Delta G_{T}$ で特性づけられると思わ れる.またこの現象は，界面・接着材・被着材の伝ぱ 抵抗がこの場合あまり差がないことに起因するものと 考えられる.

また接着継手の混合モード破壊基準は，静的破壊と

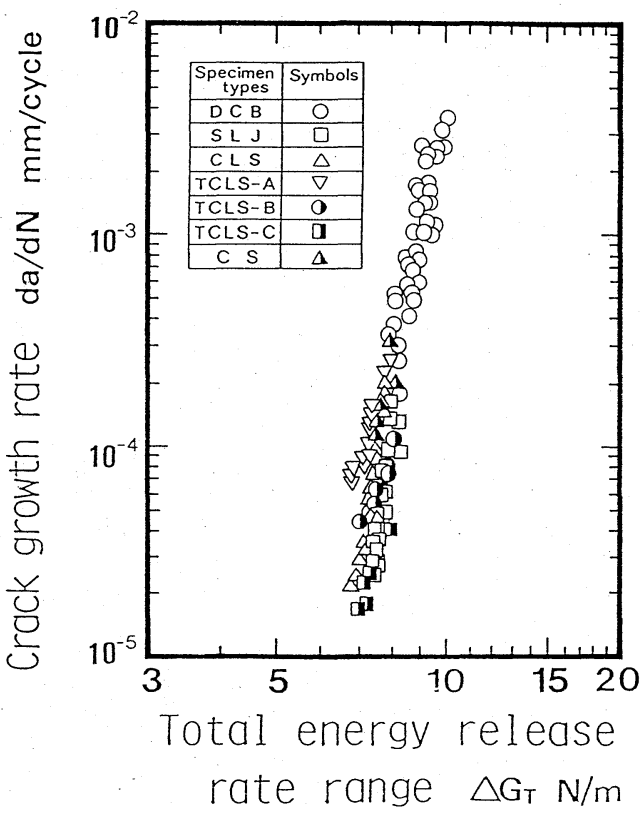

Fig. 10. Mixed mode fatigue crack growth properties of various adhesive joints (Acryl, Cemedine 1500). 
疲労破壊で全く異なることが明らかとなった.

$$
7 \text { 結 言 }
$$

接着継手の強度を破壊力学的に評価する際, 特 に重要と考えられる混合モード破壊基準について 検討し, 以下の主な結論を得た。

（1）接着継手の形状を工夫し，広範囲な混合モ 一ド状態を実現し, 各種継手の静的破壤実験を行 なった．接着継手特有の混合モード破壊基準を明 らかにした.

(2) 接着継手の破壊力学パラメー夕 $G_{\mathrm{I}}, G_{\mathrm{II}}$ の 評価法として FEM 解析を援用し， $G_{\mathrm{I}} / G_{\mathrm{II}}$ の比を 用いて分離評価する方法を提案した。

（3）静的破壊の混合モード破壊基準として，2 パラメータ，2クライテリオン的定式化を提案し た. また均質材のクライテリオンを同一罒に表示 し，母材破壊か接着界面破壊かを簡便に判定する 方法を示した.

（4）接着継手の静的破壊と疲労破壊とでは全く 異なる混合モード破壊基準が必要となることを明 らかにした．接着継手の混合モード疲労き裂伝ぱ は全エネルギ解放率範囲 $\Delta G_{T}$ で統一的に評価で

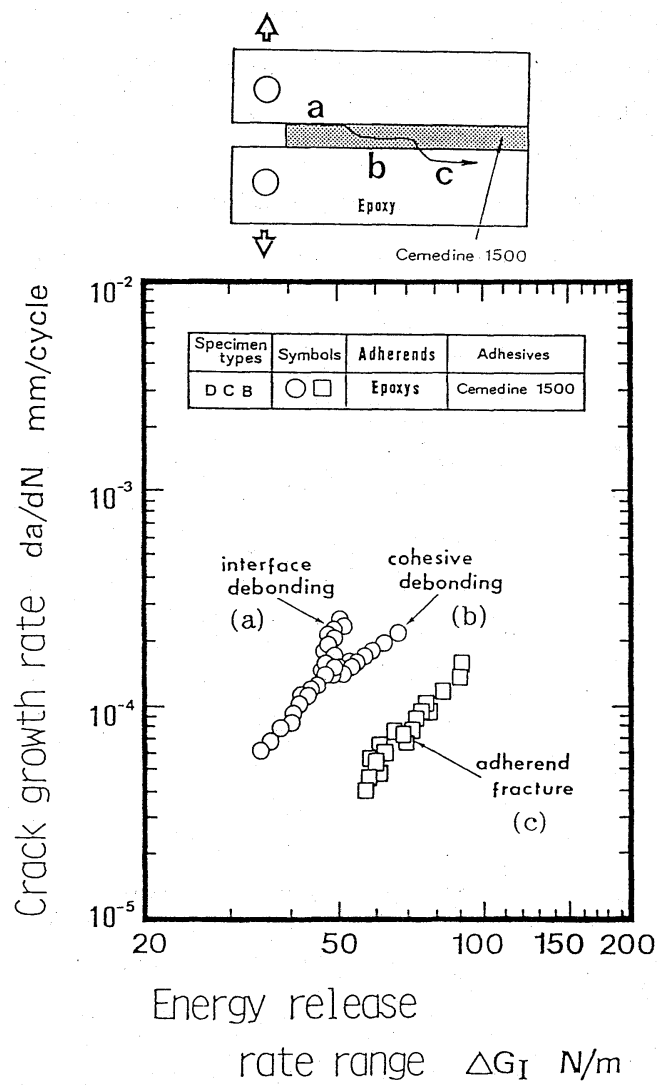

Fig. 12. Fatigue crack growth of DCB adhesive joint (Epoxy, Cemedine 1500).

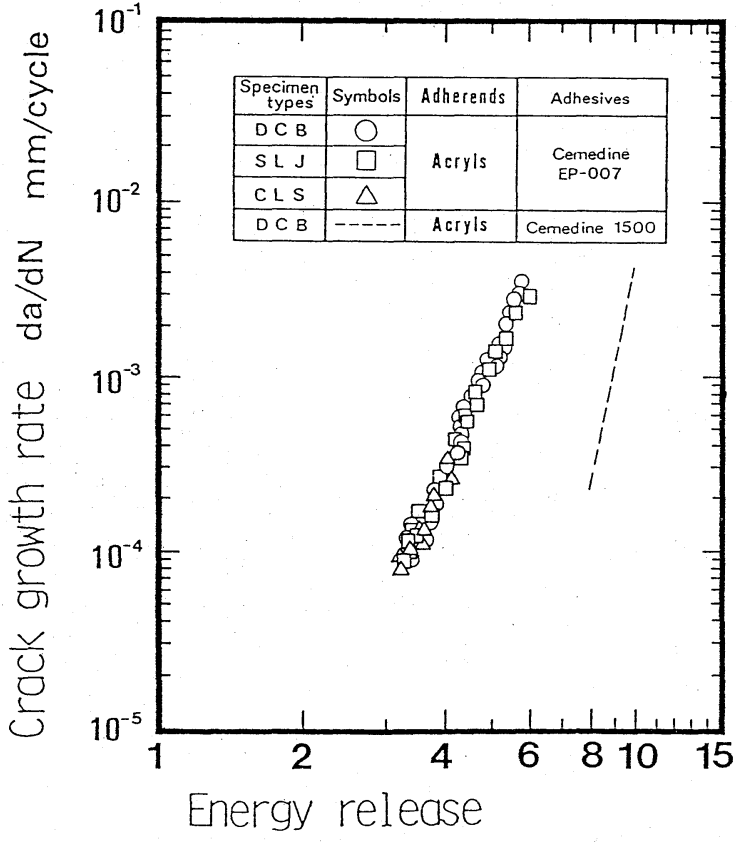

rate range $\triangle \mathrm{G}_{\mathrm{T}} \quad \mathrm{N} / \mathrm{m}$

Fig. 11. Mixed mode fatigue crack growth properties of various adhesive joints (Acryl, Cemedine EP-007).

きた。

（平成元年 9 月 27 日 第 5 回破壊力学シンポジウムにて講演）

\section{参 考 文 献}

1 ) 鄭 南龍, 結城良治, 石川晴雄, 中野 禅, 日本機械学 会論文集，A-54，1895（1988）。

2 ) G. G. Trantina, J. Compos. Mater., 6, 371 (1972).

3) S. Mall, M. A. Rezaizadeh and G. Ramamurthy, Trans. ASME, J. Eng. Mater. and Technol., 109, 17 (1987).

4) R. A. Everett, NASA TM-84504, National Aeronatics and Space Administration (1982).

5 ) T. R. Brussat and S. T. Chiu, Trans. ASME, J. Eng. Mater. Technol., 100, 39 (1978).

6) S. Mall and W. S. Johnson, ASTM STP 893, 322 (1986).

7) C. Lin and K. M. Liechti, J. Adhes., 21, 1 (1987).

8 ) S. Mall and K. T. Yun, J. Adhes., 23, 215 (1987).

9 ) 石川晴雄, 中野 禅, 結城良治, 鄭、南龍, 日本機械学 会論文集，A-55，937 (1989).

10） CRACK/PC マニュアル（1989）CRC (株)

11) E. F. Rybichi, T. D. Hernandez, Jr., J. E. Deibler, R. C. Knight and S. S. Vinson, J. Compos. Mater, 21, 105 (1987).

12）鄭 南龍, 結城良治, 石川晴雄, 中野 禅, 日本機械学 会論文集，A-55，1984（1989）.

13）北條正樹， C. G. Gustafson, 田中啓介，林 龍一，材料， 36, 222 (1987). 